\title{
Gambaran Radiologis Foto Polos pada Pasien Sinusitis di Rumah Sakit Sekarwangi Periode Juni 2015 - Juni 2016
}

\section{The Plain Radiological Description of Sinusitis Patient in Sekarwangi Hospital in The Period of J une 2015-J une 2016}

\author{
Putri Shabrina Amalia ${ }^{1}$, Arroyan Wardhana ${ }^{2}$ \\ ${ }^{1}$ Student of Faculty of Medicine, YARSI University, Jakarta \\ ${ }^{2}$ Department of ENT, Faculty of Medicine, YARSI University, Jakarta
}

\begin{abstract}
Abstrak
Sinusitis adalah inflamasi mukosa sinus paranasal yang dapat disebabkan infeksi bakteri, virus, kelainan struktur anatomi, atau infeksi pada gigi. Penegakkan diagnosis sinusitis juga ditunjang dengan pemeriksaan radiologis foto polos. Foto polos memiliki spesifitas $96-100 \%$ dan sensitivitas $70 \%$. Jenis foto polos yang sering digunakan adalah foto Waters. Penelitian ini bertujuan mengetahui gambaran foto polos radiologis pada pasien sinusitis di RS Sekarwangi pada periode Juni 2015-Juni 2016. Penelitian ini menggunakan rancangan penelitian deskriptif kuantitatif. Teknik pengambilan sampel dengan cara total sampling. Total responden penelitian adalah 50 responden dengan kriteria terdiagnosis sinusitis di RS Sekarwangi pada periode Juni 2015-Juni 2016. Pengambilan data menggunakan observasi pada rekam medik dan hasil interpretasi ahli radiologi pada foto polos Waters untuk menunjang diagnosis sinusitisnya. Analisis penelitian menggunakan distribusi frekuensi. Hasil penelitian menunjukan sebagian besar kasus adalah laki-laki, 52\% menderita sinusitis, dengan umur terbanyak adalah 46-60 tahun, dan lokasi infeksi terbanyak pada sinusitis maksilaris bilateral. Gambaran khas foto polos terbanyak adalah perselubungan dan tidak ditemukan gambaran air fluid level.
\end{abstract}

Kata Kunci: Sinusitis foto polos foto Waters radiologi

\section{Abstract}

Sinusitis is a mucosal inflammation of the paranasal sinuses that can be caused by bacterial, viral, anatomical structural abnormalities, or infection of the teeth. The diagnosis of sinusitis is also supported by the plain radiological. The plain radiography has a specificity of $96-100 \%$ and sensitivity of $70 \%$. The plain radiography that often used for the investigation of sinusitis is photos of Waters. This study aims is to know the description of the plain radiography in sinusitis patients at RS Sekarwangi in the period of June 2015-June 2016. This research uses descriptive quantitative research design. The sampling collection was done by total sampling. Total survey respondents were 50 respondents with the respondents' criteria as the patients diagnosed with sinusitis in RS 
Sekarwangi in the period of June 2015-June 2016. Data collection using observation in the medical record and interpretation of radiologists on plain radiography. The data was analyzed by using frequency distribution. In this study, most cases are men in the amount of $52 \%$ suffer from sinusitis, with 46-60 years age is the most common and bilateral maxillary sinusitis is the most common location of the infection. A typical description of Photo Waters is haziness and there is no image of airfluid level.

Keywords: Sinusitis, plain photo, photo Waters, radiology

\section{Pendahuluan}

Sinusitis adalah inflamasi mukosa sinus paranasal yang dapat disebabkan karena infeksi virus, infeksi bakteri, atau kelainan struktur anatomi (Sundaru, 2014). Sinus paranasal yang sering terkena adalah sinus etmoidalis dan sinus maksilaris (Mangunkusumo, 2015). Penderita sinusitis biasanya mengeluhkan gejala seperti nyeri di muka dan pipi, pusing, hiposmia, dan batuk. Dapat juga ditemukan adanya nyeri tekan di daerah sinus, mukosa hidung kemerahan, dan sekret yang purulen (Sundaru, 2014).

Diagnosis sinusitis dapat ditegakkan berdasarkan riwayat penyakit, pemeriksaan fisis, sitologi sekret hidung dan pemeriksaan radiologi. Pemeriksaan radiologi diperlukan jika gejala tidak jelas, hasil pemeriksaan fisik meragukan atau respons pengobatan tidak memuaskan (Sundaru, 2014). Dengan pemeriksaan radiologi, akan didapatkan gambaran anatomi atau variasi anatomi, kelainan patologis pada sinus paranasalis dan struktur tulang di sekitarnya, sehingga dapat menegakkan diagnosis secara lebih dini (Rachman, 2013).

Pemeriksaan radiologi untuk menegakkan diagnosis sinusitis dapat dengan menggunakan foto polos atau Computed Tomography (CT) Scan. Sampai pada dewasa ini, foto polos masih digunakan untuk mendeteksi foreign bodies pada suspek sinusitis
(Aras, 2014). Foto polos memiliki spesifitas yang tinggi untuk melihat gambaran semua sinus, sensitivitas sebesar $80 \%$ untuk sinus maxillaris, dan sensitivitas yang lebih rendah untuk sinus ethmoidalis, sinus sphenoidalis, dan sinus frontalis. (Aaløkken, 2014). Hal ini serupa dengan Burke et al. (dikutip dalam Aras, 2014), yang melaporkan bahwa spesifitas foto polos sebesar $96-100 \%$ dan sensitivitas foto polos sebesar 70\%. Meskipun demikian, foto polos lebih sering digunakan untuk menunjang diagnosis sinusitis, dikarenakan pemeriksaan dengan foto polos tidak membutuhkan biaya yang mahal, tersedianya alat pemeriksaan dalam jumlah yang memadai di rumah sakit, dan waktu pemeriksaan yang cepat (Aalokken, 2014).

Pada beberapa rumah sakit atau klinik di Indonesia, untuk mengevaluasi sinus paranasal, cukup dengan dilakukan pemeriksaan foto kepala AP dan lateral serta posisi Waters. Apabila pada foto dengan posisi tersebut belum dapat menentukan atau belum didapatkan informasi yang lengkap, maka dilanjutkan dengan pengambilan foto dengan posisi lainnya (Rachman, 2013)

\section{Bahan dan Metoda Penelitian}

Penelitian ini dilakukan pada pasien dengan diagnosis sinusitis di RS Sekarwangi pada periode Juni 2015 - Juni 2016 dengan 
menggunakan jenis penelitian deskriptif terbanyak pada laki-laki yaitu sebanyak 26 orang kuantitatif. Rancangan penelitian ini dilakukan (52\%), sedangkan pada perempuan terdapat 24 secara cross sectional dengan mengolah data sekunder dari rekam medis dan berdasarkan hasil interpretasi ahli radiologi pada foto polos. Sampel penelitian ini ditentukan dengan metode total sampling pada pasien dengan diagnosis sinusitis di RS Sekarwangi periode Juni 2015 Juni 2016. Pada penelitian ini mengeksklusikan pasien sinusitis dengan foto polos radiologi (-) atau tanpa foto polos. Analisa data dilakukan dengan analisis univariat untuk mengumpulkan data hasil pengukuran dengan menggunakan Microsoft Excel.

\section{Hasil Penelitian}

Selama periode 1 Juni 2015 - 31 Juni 2016, didapatkan jumlah penderita dengan diagnosis klinis pada data rekam medis dan hasil interpretasi di Bagian Radiologi RS Sekarwangi, Sukabumi sebanyak 50 penderita (Tabel 1.). Dari orang (48\%).

Pada penelitian ini didapatkan penderita sinusitis terbanyak pada kelompok usia 46 - 60 tahun sebanyak 19 orang (38\%) dan yang paling sedikit pada kelompok usia $0-15$ tahun yaitu sebanyak 5 orang (10\%) (Tabel 3.). Dari Tabel 4, didapatkan data penderita sinusitis maksilaris bilateral sebanyak 20 orang $(36,36 \%)$, yang bukan sinusitis sebanyak 3 orang (5,45\%). Dan tidak didapatkan penderita pada sinus sfenoidalis. Total sinus yang terinfeksi melebihi jumlah sampel pada penelitian ini karena responden dapat menderita lebih dari satu sinusitis atau multisinusitis.

Dari tabel 10 didapatkan gambaran foto polos terbanyak adalah perselubungan sebanyak 26 orang (52\%). Gambaran penebalan mukosa sebanyak 21 penderita (42\%). Dan tidak ditemukan gambaran air fluid level.

Tabel 2., didapatkan penderita sinusitis

Tabel 1. Distribusi Jenis Foto Polos Radiologi Pada Pasien Sinusitis di RS Sekarwangi

\begin{tabular}{ccc}
\hline Jenis Foto Polos Radiologi & $\mathbf{n}$ & $\%$ \\
\hline Waters & 50 & 100 \\
Caldwell & 0 & 0 \\
Submentoverteks & 0 & 0 \\
Rhese & 0 & 0 \\
Towne & 0 & 0 \\
\hline Total & 50 & 100
\end{tabular}

Tabel 2. Distribusi Jenis Kelamin Pasien Sinusitis di RS Sekarwangi

\begin{tabular}{ccc}
\hline Jenis Kelamin & $\mathbf{n}$ & $\%$ \\
\hline Laki - laki & 26 & 52 \\
Perempuan & 24 & 48 \\
\hline Total & 50 & 100 \\
\hline
\end{tabular}


Tabel 3. Distribusi Usia Pasien Sinusitis di RS Sekarwangi

\begin{tabular}{ccc}
\hline Usia (tahun) & $\mathbf{N}$ & $\%$ \\
\hline $0-15$ & 5 & 10 \\
$16-30$ & 8 & 16 \\
$31-45$ & 12 & 24 \\
$46-60$ & 19 & 38 \\
$>60$ & 6 & 12 \\
\hline Total & 50 & 100
\end{tabular}

Tabel 4. Distribusi Jenis Sinusitis dan Lokasi Sinusitis pada Pasien Sinusitis di RS Sekarwangi

\begin{tabular}{cccc}
\hline Sinusitis & \multicolumn{3}{c}{ Lokasi Sinusitis } \\
\cline { 2 - 4 } & Kanan (\%) & Kiri $(\%)$ & Bilateral (\%) \\
\hline Maksilaris & $13(23,64)$ & $14(25,45)$ & $20(36,36)$ \\
Frontalis & $1(1,82)$ & $1(1,82)$ & $2(3,64)$ \\
Ethmoidalis & $1(1,82)$ & 0 & 0 \\
Sfenoidalis & 0 & 0 & 0 \\
Bukan Sinusitis & & $3(5,45)$ & \\
\hline Total & & $55(100,0)$ &
\end{tabular}

Tabel 5. Distribusi Gambaran Foto Polos Radiologi pada Pasien Sinusitis di RS Sekarwangi

\begin{tabular}{ccc}
\hline Gambaran Foto Polos & $\mathbf{n}$ & $\%$ \\
\hline Penebalan mukosa & 21 & 42 \\
Air fluid level & 0 & 0 \\
Perselubungan & 26 & 52 \\
Tidak Ada Kelainan & 3 & 6 \\
\hline Total & 50 & 100
\end{tabular}

Diskusi

Pada data pada Tabel 1, didapatkan bahwa semua pasien sinusitis di RS Sekarwangi pada periode Juni 2015-Juni 2016 sebanyak 50 orang $(100 \%)$ melakukan foto polos dengan posisi Waters. Penelitian yang dilakukan Posumah (2013) mendapatkan hasil yang serupa yakni sejumlah 97 orang (100\%) menggunakan foto polos Waters untuk mendiagnosis sinusitis, hal serupa juga didapatkan pada penelitian oleh Wardani et al
(2014) dimana 45 orang (100\%) penderita sinusitis juga menggunakan foto polos Waters.

Posisi rutin yang digunakan untuk menegakkan diagnosis sinusitis adalah posisi Waters, PA, dan lateral. Posisi waters terutama digunakan untuk melihat adanya kelainan di sinus maksilaris, frontalis, dan etmoidalis. Posisi postero-anterior untuk menilai sinus frontalis, dan posisi lateral untuk menilai sinus frontalis, sfenoidalis dan etmoidalis (Mangunkusumo, 2014). Pada foto Waters secara ideal piramis tulang petrosum diproyeksikan pada dasar sinus 
maksilaris sehingga kedua sinus maksilaris dapat dievaluasi seluruhnya. Foto Waters umumnya dilakukan pada keadaan mulut tertutup. Pada posisi mulut terbuka akan dapat menilai daerah dinding posterior sinus sfenoidalis dengan baik (Rachman, 2013).

Berdasarkan data Tabel 2, sinusitis lebih banyak diderita oleh laki-laki yaitu sebanyak 26 orang $(52 \%)$, sedangkan pada perempuan terdapat 24 orang (48\%). Hasil penelitian ini tidak jauh berbeda dengan peneliti - peneliti sebelumnya, seperti yang didapatkan oleh Septiwati et al. (2013) dimana sampel sinusitis pasien laki - laki sebanyak 20 orang (52,8\%) dan perempuan sebanyak 14 orang $(41.2 \%)$. Hal ini berbeda dengan hasil yang didapatkan oleh Arivalagan et al. (2013) dan Posumah (2013) yang mendapatkan penderita perempuan lebih banyak daripada penderita laki-laki.

Lingkungan berpolusi, udara dingin dan kering serta kebiasaan merokok adalah beberapa faktor yang berpengaruh pada sinusitis. Kebiasaan merokok pada laki - laki menyebabkan mereka lebih terpapar dengan zat toksik yang dapat mempengaruhi sistem imun tubuh, sehingga sinusitis lebih banyak diderita oleh laki - laki. (Dalimunthe, 2010)

Menurut data Tabel 3, didapatkan penderita sinusitis terbanyak pada kelompok usia 46-60 sebanyak 19 orang (38\%). Penelitian yang dilakukan Posumah (2013) mendapatkan penderita sinusitis dengan frekuensi tertinggi berada di kelompok usia 30-44 sebanyak 24 orang (40\%). Demikian pula dengan penelitian yang dilakukan oleh Arivalagan et al. (2013) yang mendapatkan kelompok usia 31-45 sebanyak 60 orang $(31,6 \%)$. Pada penelitian yang dilakukan oleh Wardani et al (2014) didapatkan penderita sinusitis pada kelompok usia 34-48 sebanyak 15 orang (33,33\%).
Data penelitian di atas menunjukkan umur penderita sinusitis yang paling banyak dari kelompok usia dewasa. Menurut Dalimunthe (2010), hal tersebut mungkin disebabkan kelompok usia dewasa merupakan kelompok usia yang aktif dan sering terpapar oleh polutan atau zat-zat iritan yang mungkin dapat menyebabkan atau memperberat terjadinya sinusitis maksilaris, sehingga lebih banyak penderita dengan kelompok usia dewasa yang datang berobat ke rumah sakit.

Menurut data pada Tabel 4, didapatkan penderita sinusitis maksilaris bilateral sebanyak 20 orang $(36,36 \%)$. Pada data ini juga didapatkan yang bukan sinusitis sebanyak 3 orang $(5,45 \%)$. Dan tidak didapatkan penderita pada sinus sfenoidalis. Hal ini berbeda dengan penelitian yang dilakukan Arivalagan et al. (2013) dimana didapatkan penderita sinusitis maksilaris unilateral sebanyak 92 orang $(48,4 \%)$. Data penelitian ini selaras dengan penelitian Wardani et al. (2014) yang mendapatkan jumlah penderita sinusitis maksilaris bilateral sebanyak 24 orang $(53,34 \%)$.

Sinus maksilaris adalah sinus paranasal terbesar dan yang paling sering terkena infeksi karena ostium sinus maksilaris terletak lebih tinggi dari dasar sinus, sehingga drainase hanya tergantung dari gerak silia, dan drainase juga harus melalui infundibulum yang sempit. Hambatan pada pergerakkan silia akan menyebabkan sekret terkumpul dalam sinus yang dapat menjadi media pembiakan bakteri (Arivalagan et al., 2013)

Pada dinding lateral hidung terdapat 2 aliran transport mukosiliar dari sinus. Lendir yang berasal dari kelompok sinus anterior yang bergabung di infundibulum etmoid dialirkan ke nasofaring di depan muara tuba eustachius. Lendir yang berasal dari kelompok sinus 
posterior bergabung di resesus sfenoetmoidalis dan dialirkan ke nasofaring postero-superior muara tuba. Hal inilah yang menyebabkan pada penderita sinusitis, sering didapati post nasal drip, namun belum tentu ada sekret di rongga hidung (Rachman, 2013).

Terjadinya sinusitis bilateral dapat disebabkan oleh berbagai faktor seperti kelainan struktur anatomi hidung ataupun infeksi virus. Selain itu, prosesus alveolaris yang merupakan dasar sinus maksilaris dan tempat akar gigi premolar dan molar atas, hanya dibatasi oleh tulang tipis dengan akar gigi bahkan kadang tanpa pembatas. Sehingga jika terjadi infeksi apikal akar gigi atau inflamasi periodontal, maka dapat mudah menyebar secara langsung ke sinus melalui pembuluh darah dan pembuluh limfe (Mangunkusumo, 2015).

Sedangkan menurut Rachman (2013), sinusitis yang disebabkan oleh infeksi bakteri lebih sering menyerang sinus paranasal secara unilateral. Pada sinusitis alergika, sinus yang terserang secara bilateral dan biasanya disertai poliposis nasal.

Berdasarkan data pada Tabel 5, gambaran foto polos terbanyak adalah perselubungan sebanyak 26 penderita (52\%). Gambaran penebalan mukosa sebanyak 21 penderita (42\%). Dan tidak ditemukan gambaran air fluid level. Hal ini sesuai dengan penelitian Posumah (2013) yang mendapatkan gambaran foto Waters terbanyak adalah perselubungan sebanyak 43 penderita (76,67\%). Dan tidak ditemukan gambaran air fluid level pada penderita sinusitis maksilaris. Pada penelitian oleh Wardani et al (2014) 7 orang penderita $(15,56 \%)$ dengan penebalan mukosa, 15 orang penderita $(33,33 \%)$ dengan perselubungan, 2 orang penderita (4,44\%) dengan air fluid level.

Hasil dari peneliti - peneliti sebelumnya memiliki gambaran yang hampir sama, dimana gambaran foto Waters pada penderita sinusitis maksilaris yang paling sering ditemukan adalah gambaran perselubungan, sedangkan yang terendah ditemukan adalah gambaran air fluid level (Wardani et al, 2014). Menurut Rachman (2013), hampir 50\% kasus-kasus dengan perselubungan pada salah satu sinus maksilaris pada posisi tidur (supine), ternyata merupakan gambaran air-fluid level ketika foto diambil dalam posisi duduk.

\section{Simpulan}

Pada penelitan ini didapatkan hasil sebanyak 50 orang (100\%) pasien sinusitis menggunakan foto polos Waters untuk menunjang diagnosis sinusitisnya. Penderita sinusitis di RS Sekarwangi paling banyak berjenis kelamin laki-laki, yakni sebanyak 26 orang (52\%). Pada kelompok usia 46-60 didapatkan data penderita sinusitis terbanyak yaitu 19 orang (38\%). Penderita sinusitis maksilaris bilateral didapatkan sebanyak 20 orang (36,36\%). Gambaran foto polos terbanyak adalah perselubungan yaitu sebanyak 26 orang (52\%).

\section{Daftar Pustaka}

Aalokken, T. H. (2014). Conventional sinus radiography compared with $\mathrm{CT}$ in the diagnosis of acute sinusitis. The British Institute of Radiology.

Aras, O. M. (2014). Comparison of the sensitivity for detecting foreign bodies among conventional plain radiography, computed tomography and ultrasonography. The British Institute of Radiology.

Arivalagan P, Rambe A. (2013). Gambaran Rinosinusitis Kronik di RSUP Haji Adam 
Malik pada Tahun 2011. E-Jurnal FKUSU, 1(1), pp. 1-6.

Dalimunthe SA. (2011). Gambaran penderita rinosinusitis di RSUP. Haji Adam Malik Medan pada tahun 2010 [Karya Tulis Ilmiah]. Medan: Fakultas Kedokteran USU/RSU H. Adam Malik

Mangunkusumo, E. (2015). Telinga, Hidung, Tenggorok, Kepala \& Leher (7 ed.). (S.-K. Prof. dr. Efiaty Arsyad Soepardi, Penyunt.) Jakarta: Badan Penerbit FKUI.

Posumah. (2013) Gambaran Foto Waters pada penderita dengan dugaan sinusitis maksilaris di RSUP Prof. Dr.R.D. Kandou Manado. Jurnal e-Biomedik (eMB).

Rachman, M. D. (2013). Radiologi Diagnostik (2 ed.). (I. Ekayuda, Ed.) Jakarta: Badan Penerbit FKUI.
Septiwati M, Taher A, Rahayu U. (2013). Hubungan infeksi gigi rahang atas dengan kejadian rhinosinusitis maksilaris di RSUD Raden Matteaher Jambi. The Jambi Medical Journal.

Sundaru, H. (2014). Buku Ajar Ilmu Penyakit Dalam (5 ed., Vol. 1). (A. W.Sudoyo, B. Setiyohadi, I. Alwi, M. S. K, \& S. Seliati, Penyunt.) Jakarta: Interna Publishing.

Wardani, N., Ali, L., Loho, E. (2014). Hubungan Gambaran Foto Waters dan Gejala Klinik Pada Penderita Dengan Dugaan Sinusitis Maksilaris Di RSUP Prof Dr. R. D. Kandou Manado Periode 1 Oktober 2012-30 September 2013. Jurnal E-Clinic, 2(1), pp. 1-7. 